Kindness in Management and Organizational Studies 


\section{Kindness at Work}

Series Editor: Michelle Thomason, $\mathrm{PhD}$

Kindness at Work is a ground-breaking series expanding critical discussion within Business and Management by examining the concept of kindness in a business context.

Examining multiple perspectives on the understanding, interpretation, enactment, and resistance to the concept of kindness, Kindness at Work brings together leading scholars to explore this is in relation to different areas of business theory and practice.

Kindness at Work provides illuminating new perspectives and insight to scholars analysing leadership style, organizational psychology and HR practice and theory, as well being relevant to broader range of Social Science research areas.

\section{Forthcoming Titles}

- Leadership and Kindness

- Making HR Kinder

- Indigenous Understandings of Kindness

- Kindness, Black Lives and Work

- Kindness, Work and Wellbeing 


\section{Kindness in Management and Organizational Studies}

\section{EDITED BY}

MICHELLE THOMASON, PHD

Independent Researcher, Canada

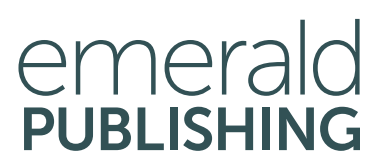

United Kingdom - North America - Japan - India - Malaysia - China 
Emerald Publishing Limited

Howard House, Wagon Lane, Bingley BD16 1WA, UK

First edition 2022

Editorial matter and selection (C) 2022 Michelle Thomason. Published under exclusive licence by Emerald Publishing Limited.

Individual chapters $(C) 2022$ the authors. Published under exclusive licence by Emerald Publishing Limited.

\section{Reprints and permissions service}

Contact: permissions@emeraldinsight.com

No part of this book may be reproduced, stored in a retrieval system, transmitted in any form or by any means electronic, mechanical, photocopying, recording or otherwise without either the prior written permission of the publisher or a licence permitting restricted copying issued in the UK by The Copyright Licensing Agency and in the USA by The Copyright Clearance Center. Any opinions expressed in the chapters are those of the authors. Whilst Emerald makes every effort to ensure the quality and accuracy of its content, Emerald makes no representation implied or otherwise, as to the chapters' suitability and application and disclaims any warranties, express or implied, to their use.

\section{British Library Cataloguing in Publication Data}

A catalogue record for this book is available from the British Library

ISBN: 978-1-80262-158-7 (Print)

ISBN: 978-1-80262-157-0 (Online)

ISBN: 978-1-80262-159-4 (Epub) 
To my ELDO for my love of books and my mother for her huge kind heart. 
This page intentionally left blank 


\section{Table of Contents}

List of Figures and Tables ix

About the Contributors $x i$

Foreword $x v$

Acknowledgements xvii

Chapter 1 Patterns and Possibilities: Exploring the Meaning of Kindness

Kristin S. Williams and Heidi Weigand

Chapter 2 Choosing Kindness: Finding Kindness in Management and Organization Studies

Kristene E. Coller

Chapter 3 Strength through Kindness: Celebrating the Success of Women Leaders and Feminine Leadership Styles

Danielle Mercer-Prowse

Chapter 4 Communicating Kindness at Work Amy Thurlow

Chapter 5 Kindness as an Imperative 
Chapter 6 Leading with Compassion: Co-designing a Workshop That Responds to a Report of Sexual Harassment or Discrimination with Unbiased Compassion

Shelley T. Price, Megan Fogarty, De-Ann Sheppard, Grace Campbell, Sarah Cartwright, Kylie Ito, Rachel MacDonald, Sabrina Guzman Skotnitsky, Heidi Weigand and Krista Smith

Chapter 7 Care Ethics and Kindness in Management and Organizational Studies

Nina Winham

Chapter 8 Intergenerational Stories of Kindness: A Catalyst for Bouncing Back

Heidi Weigand, Heather Mackinnon, Erica Weigand and Jessica Hepworth

Chapter 9 Dear Masie: A Story-net of Kindness

Tammy Williams and Heidi Weigand

Chapter 10 Be a 'Good Girl': The Durability and Enigmatic Nature of Benevolent Sexism as a Form of Performative Kindness

Kristin S. Williams

Chapter 11 Conceptualizing and Constructing Kindness

Michelle Thomason

Index 


\section{List of Figures and Tables}

Figure 1. Kindness at Work (Author's Original Work). 174

Table 1. Pre Co-design Agenda. 82

Table 2. Post Co-design Agenda. 86

Table 3. Themes Emerging from the Scripting Process. 90

Table 1. Intergenerational Perspectives of Kindness in My Family (Authors' Original Work). 
This page intentionally left blank 


\section{About the Contributors}

Marcelle Allen, MBA, PhD, is a Business Faculty at Northern Lights College, Dawson Creek, British Columbia. Prior to Northern Lights College, she held various industry positions and also taught at Schulich School of Business, University of Toronto and Seneca College. She has MBA from Schulich School of Business, York University, and PhD Management from Sobey School of Business, Saint Mary's University. Her primary research interest is the role of business in shaping society.

Grace Campbell is dedicated to ensuring a safe and equitable learning environment through her work as a secondary school educator. She holds a Bachelor of Business Administration and is a recent graduate from the Bachelor of Education programme, in which she specialized in secondary business and mathematics education. Keen to be involved in her local community, Grace took on various volunteer and leadership roles throughout her time as a student at St. Francis Xavier University. The volunteer opportunity that stands out the most to Grace is her time spent with $\mathrm{X}$ project. X Project is an organization dedicated to working with African Canadian and Mi'kmaq youth to provide educational assistance, and recreational and leadership programmes. Grace is eager to begin her career as a secondary school educator and to continue to promote the benefits of business education with the school system.

Sarah Cartwright was born and raised in Toronto, Ontario. She attended St. Francis Xavier University where she completed her Bachelor of Business Administration Degree with an Advanced Major in Finance. In her final year of university, she participated in the Gender and Management course where she studied the impact of leading with compassion in the workplace. Sarah now works as a Business Development Manager in the financial industry where she applies the concepts from her Gender and Management class to be a better leader, colleague and friend. She believes that the study of compassionate leadership in the workplace is necessary for an organization to create a healthy and sustainable working environment.

Kristene E. Coller, PhD at the Sobey School of Business (Saint Mary's University), is currently studying the neglect of Canadian management thought. As a lecturer for the University of Lethbridge (Calgary Campus) and Mount Royal University, Kristene tries to incorporate kindness into her approach to teaching and working with colleagues and has been fortunate to experience many acts of kindness 
throughout her personal and professional life. Kristene writes on a variety of topics including management history, health care, workplace health promotion and the imposter syndrome and is passionate about getting people to think about topics from a different perspective.

Megan Fogarty, MIR, CFP-B believes that investigations can be fair, neutral and trauma informed. She has worked as the Subject Matter Expert on Human Rights and Equity in Atlantic Canada for Canada Post and is currently the Manager of Human Rights and Equity at St. Francis Xavier University in Antigonish, NS. She has received training in trauma-informed interviewing and holds a Master's degree in Industrial Relations from Queen's University.

Jessica Hepworth, BA Psychology, is working on her second degree, a Bachelor of Social Work at Dalhousie University in Halifax, Nova Scotia.

Kylie Ito is a proud multiracial Canadian woman who was born and raised in Cobourg, Ontario. She now resides in Halifax, Nova Scotia, after graduating from St. Francis Xavier University in 2019 with a BBA. During her time there she founded a Mental Health Emergency Bursary to provide financial support to those experiencing mental health concerns. She currently works at a tech startup company called Dash Hudson, partnering with some of the world's largest brands to improve their social media performance. Kylie takes pride in her role as a coach in Athletics to young women in her community.

Rachel MacDonald is a passionate future educator who believes in the rights for all persons to exist in a safe and positive work environment. After graduating from St. Francis Xavier University in 2020 with a Bachelor of Business Administration, she currently resides in Halifax, Nova Scotia, where she is completing her first year in the Bachelor of Education programme at Mount Saint Vincent University. As a future elementary school educator, Rachel believes that compassionate leadership and emotional intelligence are important aspects to establishing safe and positive work environments.

Heather Mackinnon, MSc MD, is a former military physician practicing in Halifax.

Danielle Mercer-Prowse is an Assistant Professor in Management at Acadia University in Wolfville, Nova Scotia, Canada. She has a PhD in Management from the Sobey School of Business, St. Mary's University, Halifax, Nova Scotia, Canada. In 2013, she was awarded a Social Sciences and Humanities Research Council of Canada Joseph-Armand Bombardier Doctoral Scholarship for her studies in gender and leadership. Her dissertation focused on the development, validation and testing of a team androgyny measure related to decision-making styles within the context of business organizations. Broadly, her research interests examine the interplay between gender, leadership and workplace well-being.

Shelley T. Price, BComm, MBA, PhD, is an Assistant Professor at StFX University. Shelley is an Inuk woman born in Labrador, Canada. She currently resides in Mi'kma'ki, the ancestral and unceded territory of the Mi'kmaq. 
Shelley's work calls for trauma-informed and culturally humble approaches to leadership. She works with Indigenous storytelling, collective and affective leadership, and land-based wisdom.

De-Ann Sheppard is a proud L'nu woman of Mi'kmaw and Irish descent. She currently lives, works and plays in Mi'kma'ki, on the shore of St. George's Bay. Having had the privilege of working as a nurse practitioner for over 30 years in many rural and remote Indigenous communities across Canada, her scholarship is dedicated to trauma-informed, culturally safe and contextualized advocacy, while reclaiming L'nu epistemologies through the Mi'kmaw language. Ksaltultinej, Ankua'toq, aq Ewlite'taqn (Love, Care and Compassion) are animated in her writing. Both as a PhD student and Assistant Professor of Nursing, she embraces decolonized teaching and research spaces as places for transformative healing.

Sabrina Guzman Skotnitsky is a Climate Justice Advocate residing on the unceded territory of the Musqueam, Tsleil-Waututh and Squamish peoples. She holds a BA Honours in International Development Studies from Dalhousie University. As a bisexual woman with mixed Mexican and European descent, intersectionality is an important focus in her research and activism.

Krista Smith practiced labour and employment law for a decade before founding Root \& Branch Workplace Conflict Resolutions, which focuses on helping organizations prevent, navigate and recover from moments of conflict and crisis. Since workplace investigations and assessments form the core of Krista's practice, she has worked hard to design processes that are trauma-informed and procedurally fair. Her processes are informed by the foundational principle that every human being should be treated with dignity. Krista is currently serving as Senior Policy Lawyer for the Mass Casualty Commission. She resides in Dartmouth, Nova Scotia.

Michelle Thomason completed her PhD at the Sobey School of Business, Saint Mary's University in K'jipuktuk, Canada. Her research explores kindness at working, sensemaking and kindness, kindness and unkindness and psychological health and emotional safety in the workplace. She is a proud public servant and works for the Nova Scotia provincial government as Director of Organizational Health. This is the first book in her series, Kindness at Work.

Amy Thurlow is Professor of Communication at Mount Saint Vincent University in Halifax, Canada, where she teaches public relations and communication management in the Department of Communication Studies. Her research focuses on identity construction and the communicative nature of organization. She has recently published her first book, Social Media, Organizational Identity and Public Relations the Challenge of Authenticity, (2019) Routledge. She is a member of the National Education Council of the Canadian Public Relations Society and the international Commission on Public Relations Education.

Erica Weigand has a Master's degree in International Business, with a speciality in environmental sciences at Marbella University International Centre in Marbella, Spain. 
Heidi Weigand, PhD, is an Assistant Professor of Management at Dalhousie University. She is a member of the Safe Assured research team with the primary goal of ensuring the reliability of our community pharmacies. Much of her work has focused on contagious resilient leadership and intersectional studies to address systemic discrimination in the workplace.

Kristin S. Williams, PhD, is a Visiting Researcher at the University of Eastern Finland and the Historian in Residence with the Faculty of Management at Dalhousie University. She is a polemical feminist engaged in critical management studies through activist writing and narrative methods. Much of her work has focused on uncovering neglected historical female figures, overlooked theoretical approaches and organizational practices in management.

Tammy Williams has an MA in Women and Gender Studies at Saint Mary's University. Her masters research was the creation of the seven direction Indigenous research paradigm using the teachings from the medicine wheel and the traditional ways of knowing from the Mi'kmaq. Tammy is the Manager of Education at the Mi'kmaq Native Friendship centre with a focus on decolonizing education.

Nina Winham is a $\mathrm{PhD}$ candidate at the Sobey School of Business, Saint Mary's University, in Halifax, Canada. Her research explores care ethics within organizational management, workplace experience and social sustainability. Her previous careers include journalism, environmental non-profit management and sustainability communications and consulting, including service on numerous nonprofit boards. She lives in Vancouver and is a member of faculty at the Langara College School of Management. 


\section{Foreword}

This book brings together a range of scholarship on what kindness means in the context of management and organizational studies. It offers a re-examination of leadership that traditionally paid little attention to kindness and a recognition of emerging leaders who are powerful because of the ways that they integrate kindness in their leadership. Indigenous understandings of kindness are shared through a multigenerational storytelling experience. Chapters in this book offer diverse ways to engage with the concept of kindness and its meaning to individuals and organizations, students and scholars.

Chapters look at creating new ways to prepare for kind and unbiased compassionate responses to sexual assault and discrimination; constructing and conceptualizing kindness in the public service; the exploration of communicatively constituted organizations; and benevolent sexism and the ways this is propped up by performative kindness.

This book offers readers a chance to think about and reimagine kindness at work. Through the variety of explorations of this relatively new and understudied area of management and organizational studies, we now have more opportunities for learning and expanding the scholarship of kindness. 
This page intentionally left blank 


\section{Acknowledgements}

First, I must thank Amy, Heidi, Kristin, Kristene, Heidi, Marcelle, Nina and Shelley and Tammy for saying yes to and bringing this book into being. Each author brings their unique perspective to this new scholarship on kindness at work.

This book could also not exist without the care and kindness of Albert Mills, Jean Mills and Amy Thurlow's leadership in my dissertation creation.

I would also like to thank Chris Hartt for his generosity.

And special thanks to Taylor, for always being ready to listen to my book talk with support and love and Koumbie for so many things including your technological tenacity. 